\title{
Comparing difference in mean total protein, albumin and globulin based on severity of rhesus isoimmunization: a prospective study
}

\author{
Vikas Yadav $^{1 *}$, Dipika Deka², Aparna Sharma ${ }^{2}$, Vatsla Dadhwal ${ }^{2}$
}

\begin{abstract}
${ }^{1}$ Department of Obstetrics and Gynecology, Sharda Hospital, Greater Noida, Uttar Pradesh, India
${ }^{2}$ Department of Obstetrics and Gynecology, AIIMS, Delhi, India
\end{abstract}

Received: 27 April 2020

Accepted: 29 May 2020

\author{
*Correspondence: \\ Dr. Vikas Yadav, \\ E-mail: vikiyadav1789@gmail.com
}

Copyright: (c) the author(s), publisher and licensee Medip Academy. This is an open-access article distributed under the terms of the Creative Commons Attribution Non-Commercial License, which permits unrestricted non-commercial use, distribution, and reproduction in any medium, provided the original work is properly cited.

\begin{abstract}
Background: Maternal RBC alloimmunization results from exposure and response to a foreign RBC antigen. Transplacental fetal to maternal hemorrhage is the most common cause of alloimmunization. Rh incompatibility can lead to either fetuses with hydropic features or non-hydropic. The precise mechanism leading to the development of hydrops is uncertain. Biochemical markers have the potential to be used to assess the severity of problem. But of the mechanisms proposed none have been able to totally explain the phenomenon or predict the prognosis. Objective of this study wads to compare the difference in mean total protein, albumin and globulin bases on severity of isoimmunization and comparing it with normal controls.

Methods: A Total of 40 pregnant patients were enrolled which included 10 hydropic fetuses of $\mathrm{Rh}$ isoimmunised mothers, 10 non hydropic fetuses of $\mathrm{Rh}$ isoimmunized mothers. Control group included $18 \mathrm{Rh}$ positive women without any fetal complication and 2 fetuses in women undergoing cordocentesis. Blood sampling was done at time of intrauterine transfusion and sent for estimation of total proteins, albumin, globulin in fetal blood. Pregnancies were followed up till delivery and fetal outcome noted.

Results: Mean total protein, albumin and globulin between hydropic, non hydropic group and control group (3.25, 2.17 and $1.18 \mathrm{~g} / \mathrm{dl})$ in hydropic, $(4.14,2.70$ and $1.44 \mathrm{~g} / \mathrm{dl})$ in non hydropic and $(4.42,2.95$ and $1.47 \mathrm{~g} / \mathrm{dl})$ in control group respectively. Mean total protein, albumin and globulin between mild hydropic (3.43, 2.30 and $2.10 \mathrm{~g} / \mathrm{dl})$ and severe hydropic group $(2.59,1.6$ and $1.3 \mathrm{~g} / \mathrm{dl})$ respectively.

Conclusions: There was significantly lower levels of serum total proteins, albumin and globulin in hydropic fetuses as compared to non hydropic fetuses. Thus, hypoproteinemia can be considered a strong marker for development of hydrops in $\mathrm{Rh}$ isoimmunized fetuses.
\end{abstract}

Keywords: Fetal distress, Hypertension in pregnancy, Stillbirths

\section{INTRODUCTION}

$\mathrm{Rh}$ incompatibility refers to a condition developing in a $\mathrm{Rh}$-negative mother carrying a $\mathrm{Rh}$ positive fetus, due to maternal anti $\mathrm{Rh}$ antibodies; resulting in serious, sometimes life-threatening condition in the fetus- anemia, jaundice, leading to kernicterus and even death. Rh sensitization occurs in approximately 1 per 1000 births to women who are $\mathrm{Rh}$ negative. ${ }^{1}$ Levine and co-workers (1959) identified that the rhesus (Rh) antibodies on the
RBCs of affected but not unaffected neonates was the cause of the anemia. ${ }^{2}$ In 1961, haemolytic anemia became the first treatable fetal disease after Sir William Liley characterized its natural history and then successfully transfused affected fetuses intra-peritoneally with adult RBCs. ${ }^{3}$ The incidence of Rh-negative individuals varies by race. ${ }^{4}$ The vast majority $(85 \%)$ of individuals are considered $\mathrm{Rh}$ positive. $\mathrm{Rh}$ sensitization occurs in approximately 1 per 1000 births to women who are Rh negative..$^{5}$ 
All direct fetal sequelae of hemolytic disease relate to the development of anemia. However, metabolic complications develop as the anemia worsens. ${ }^{6}$ Presently ultrasound is the only tool being used for finding the severity of hydrops and cardiac failure. ${ }^{7}$ If MCA PSV value is $>1.55 \mathrm{MoM}$ intrauterine transfusion is done, also intrauterine transfusion is done in a hydropic fetus at the time of detection. ${ }^{8}$

All direct fetal sequelae of haemolytic disease relate to the development of anemia. ${ }^{9}$ There remains lacunae and need for knowing biochemical abnormalities in relation to hypoalbuminemia, cardiac failure that can be attributed to non-resolution of hydrops. The present study has therefore been planned to find the biochemical abnormalities in $\mathrm{Rh}$ isoimmunization and hydrops fetalis and also will help in predicting the development of hydrops/prognosis of hydrops/resolution of hydrops.

\section{METHODS}

This prospective study was conducted in the department of obstetrics and gynecology at AIIMS, Delhi from June 2014 to July 2016. Exclusion criteria was multiple pregnancy, patients with medical disorders, fetuses in whom cordocentesis for genetic indication detected chromosomal anomaly. Ethical clearance was obtained from the institutional ethical committee. Informed written consent was taken from the women. A Total of 40 pregnant patients were enrolled which included 10 hydropic fetuses of $\mathrm{Rh}$ isoimmunised mothers, 10 non hydropic fetuses of $\mathrm{Rh}$ isoimmunized mothers. Control group included $18 \mathrm{Rh}$ positive women who were delivered preterm without any fetal complication and 2 fetuses in women undergoing cordocentesis for genetic indication but reports came normal. Severity of hydrops was quantitated based on ascitic rim. Patients were followed up by ultrasound to look for resolution of hydrops.

\section{Examination and procedure}

$\mathrm{Rh}$ isoimmunized patients whose MCA PSV values were $>1.5 \mathrm{MoM}$ were given intrauterine transfusion of doubly irradiated and centrifuged blood. $4 \mathrm{ml}$ blood was taken for pre IUT biochemical parameters.
They were followed up by ultrasound and MCA-PSV, and subsequent Intrauterine transfusions performed when indicated as per Institute protocol of management of Rhisoimmunised pregnancies. Severity of hydrops was quantitated based on ascitic rim measured at level of hepatic vein in transverse view into $4-6 \mathrm{~mm}$ (mild) and $\geq 6 \mathrm{~mm}$ (severe).

\section{Laboratory test}

At first cordocentesis during start of IUT blood was sent for: total protein, albumin and globulin. The period of gestation at cord blood sampling of all cases was noted. Pregnancies were followed up till delivery and fetal outcome noted, at delivery PCV, total Bilirubin was again performed from cord blood.

\section{Statistical analysis}

The data were entered in Microsoft excel spread sheet and analysed using statistical product service solutions (SPSS) software IBM version 19.0. Mean values compared using analysis of variance (ANOVA). Frequency distributions were compared using Chisquare/Fisher's exact test as appropriate. A probability value of $\mathrm{p}$ value of $<0.05$ was considered for statistical significance.

\section{RESULTS}

A total of forty pregnant women attending the outpatient department of department of obstetrics and gynecology, All India Institute of Medical Sciences (AIIMS) New Delhi, were enrolled in the study it included 10 hydropic fetuses of $\mathrm{Rh}$ isoimmunised mothers, 10 non-hydropic fetuses of $\mathrm{Rh}$ isoimmunized mothers, Control group included $18 \mathrm{Rh}$ positive women without any fetal complication at 23 and 26 weeks period of gestation but were normal.

The mean age group of the patients was 29.60 years and was similar in non-hydropic, hydropic group and in control group. There was significant difference between hydrops, non-hydrops and control groups with respect to parity.

Table 1: Total proteins in cord blood sampling at first intrauterine transfusion in relation to period of gestation and presence/ absence of fetal hydrops.

\begin{tabular}{|c|c|c|c|c|}
\hline $\begin{array}{l}\text { Period of gestation } \\
\text { (weeks) }\end{array}$ & $\begin{array}{l}\text { Hydrops mean (SD) } \\
(\mathrm{gm} / \mathrm{dl})\end{array}$ & $\begin{array}{l}\text { Non hydrops mean (SD) } \\
(\mathrm{gm} / \mathrm{dl})\end{array}$ & $\begin{array}{l}\text { Control mean (SD) } \\
(\mathrm{gm} / \mathrm{dl})\end{array}$ & p value \\
\hline 20-26 weeks & $3.05(0.78 \%)$ & $3.46(0.47 \%)$ & $3.10(0.38 \%)$ & 0.715 \\
\hline $26^{+1}-32$ weeks & $3.7(0.88 \%)$ & $4.46(0.69 \%)$ & $3.62(0.53 \%)$ & 0.067 \\
\hline $32^{+1}-38$ weeks & $3.1(0.28 \%)$ & $4.20(0.58 \%)$ & $5.27(0.56 \%)$ & 0.011 \\
\hline
\end{tabular}


Table 2: Total albumin in cord blood sampling at first intrauterine transfusion in relation to period of gestation and presence/ absence of fetal hydrops.

\begin{tabular}{|lllll|}
\hline $\begin{array}{l}\text { Period of gestation } \\
\text { (weeks) }\end{array}$ & $\begin{array}{l}\text { Hydrops mean (SD) } \\
(\mathrm{gm} / \mathrm{dl})\end{array}$ & $\begin{array}{l}\text { Non hydrops mean (SD) } \\
(\mathrm{gm} / \mathrm{dl})\end{array}$ & $\begin{array}{l}\text { Control mean (SD) } \\
(\mathrm{gm} / \mathrm{dl})\end{array}$ & p value \\
\hline $20-26$ weeks & $2.13(0.54 \%)$ & $2.30(0.36 \%)$ & $1.8(0.24 \%)$ & 0.693 \\
\hline $26^{+1}-32$ weeks & $2.3(0.51 \%)$ & $2.8(0.54 \%)$ & $2.24(0.55 \%)$ & 0.159 \\
\hline $32^{+1}-38$ weeks & $1.9(0.48 \%)$ & $3.2(0.34 \%)$ & $3.70(0.45 \%)$ & 0.013 \\
\hline
\end{tabular}

Table 3: Total globulin levels in cord blood sampling at first intrauterine transfusion in relation to period of gestation and presence/absence of fetal hydrops.

\begin{tabular}{|lllll|}
\hline $\begin{array}{l}\text { Period of gestation } \\
\text { (weeks) }\end{array}$ & $\begin{array}{l}\text { Hydrops mean (SD) } \\
\text { (gm/dl) }\end{array}$ & $\begin{array}{l}\text { Non hydrops mean (SD) } \\
\text { (gm/dl) }\end{array}$ & $\begin{array}{l}\text { Control mean (SD) } \\
\text { (gm/dl) }\end{array}$ & p value \\
\hline $20-26$ weeks & $1.08(0.55 \%)$ & $1.16(0.11 \%)$ & $1.3(0.42 \%)$ & 0.904 \\
\hline $26^{+1}-32$ weeks & $1.36(0.51 \%)$ & $1.65(0.49 \%)$ & $1.37(0.32 \%)$ & 0.440 \\
\hline $32^{+1}-38$ weeks & $1.20(0.24 \%)$ & $1.0(0.10 \%)$ & $1.57(0.38 \%)$ & 0.268 \\
\hline
\end{tabular}

Table 4: Mean levels of total protein, albumin and globulin in relation to severity of hydrops.

\begin{tabular}{|llll|}
\hline Ascitic rim (MM) & Total protein $(\mathrm{g} / \mathrm{dl})$ mean (SD) & Albumin $(\mathrm{g} / \mathrm{dl})$ mean (SD) & Globulin (g/dl) mean (SD) \\
\hline $4-6$ & $3.43(0.19 \%)$ & $2.30(0.14 \%)$ & $2.10(0.15 \%)$ \\
\hline$\geq 6$ & $2.59(0.42 \%)$ & $1.6(0.13 \%)$ & $1.3(0.21 \%)$ \\
\hline $4-6$ & $3.43(0.19 \%)$ & $2.30(0.14 \%)$ & $2.10(0.15 \%)$ \\
\hline
\end{tabular}

All the patients in hydropic and non-hydropic group were multigravida. mean gestation age was 26.01 weeks (SD 3.59 , range 21.2-32.4) in hydropic group as compared to 28.3 weeks (SD 3.6, range 23.7-34.8) in non-hydropic and 31.7 weeks (SD 3.2, range 23.8-36.5) in control group and was comparable.

There were 2 with fetal ascitic rim more than $6 \mathrm{~mm}$ (severe hydrops), whereas 8 patients had fetal ascitic rim between 4-6 mm (mild hydrops). Mean total number of IUTs received by hydrops and non-hydrops was 4.90 and 3.20 respectively. $p$ value was significant $(p=0.024)$.

The mean total protein at 20-26 weeks POG in $\mathrm{Rh}$ hydrops, non-hydrops and control is $3.05,3.46$ and 3.10 $\mathrm{g} \%$ respectively. There is no significant difference in $\mathrm{p}$ value 0.000 . The mean Total protein at $26^{+1}-32$ weeks POG In RH hydrops, non-hydrops and control is 3.70 , 4.46 and $3.62 \mathrm{~g} \%$ respectively. $\mathrm{p}$ value is not significant. The mean total protein at $32^{+1}-38$ weeks POG In RH hydrops, non-hydrops and control are 3.1, 4.20 and 5.27 respectively in Table $1 . \mathrm{p}$ value is significant 0.011 .

The mean albumin at 20-26 weeks POG in Rh hydrops, non-hydrops and control is 2.13, 2.30 and $1.8 \mathrm{~g} \%$ respectively. There is no significant difference in $\mathrm{p}$ value 0.693 . The mean albumin at $26^{+1}-32$ weeks POG In RH hydrops, non-hydrops and control are 2.3, 2.8 and 2.24 $\mathrm{g} \%$ respectively. $\mathrm{p}$ value is not significant. The mean albumin at $32^{+1}-38$ weeks POG In RH hydrops, nonhydrops and control are 1.9, 3.2 and 3.70 respectively in Table 2. $\mathrm{p}$ value is significant 0.013 .
The mean globulin at 20-26 weeks POG in Rh hydrops, non-hydrops and control is 1.08, 1.16 and $1.3 \mathrm{~g} \%$ respectively. There is no significant difference in $\mathrm{p}$ value 0.904. The mean globulin at $26^{+1}-32$ weeks POG In RH hydrops, non-hydrops and control is $1.36,1.65$ and 1.37 $\mathrm{g} \%$ respectively. $\mathrm{p}$ value is not significant. The mean globulin at $32^{+1}-38$ weeks POG In RH hydrops, nonhydrops and control is $1.20,1.0$ and 1.57 respectively in Table 3. p value is not significant mean total protein, albumin and globulin between mild hydropic (3.43, 2.30 and $2.10 \mathrm{~g} / \mathrm{dl})$ and severe hydropic group $(2.59,1.6$ and $1.3 \mathrm{~g} / \mathrm{dl}$ ) respectively in Table 4.

In the present study in control group 14 women in preterm labor delivered vaginally as compared to $2 / 10$ in hydropic and 3/10 in non-hydropic group. 6 in control group underwent caesarean section for maternal/fetal indication most common being fetal distress. 8/10 in hydropic group and $7 / 10$ in non-hydropic group underwent caesarean section, most common indication being fetal anemia with poor biophysical profile. $3 / 10$ in non-hydropic group, 1/10 in hydropic group delivered after 36 weeks POG. One case with severe hydrops died in utero 2 days after IUT. All the fetuses in non-hydropic group had favourable outcome.

\section{DISCUSSION}

It has been realized since 1940 that rhesus haemolytic disease occurs when a Rh-negative mother carries a Rhpositive baby, some of the baby's Rh-positive red cells cross into the mother, where they act as a foreign antigen. 
The mother then produces an antibody to destroy this antigen in exactly the same way as she would destroy invading bacteria. Nevertheless, the difficulty is that antibody production, once initiated, is permanent, and that the $\mathrm{Rh}$ antibody (usually anti-D) will cross the placenta and damage the Rh-positive fetal cells. ${ }^{10}$

The incidence of alloimmunization varies greatly among populations. Only $15 \%$ of the population lack the $\mathrm{Rh}$ erythrocyte surface antigen and are considered Rhnegative. The vast majority $(85 \%)$ of individuals are considered $\mathrm{Rh}$ positive. $\mathrm{Rh}$ sensitization occurs in approximately 1 per 1000 births to women who are Rh negative. ${ }^{5}$

The primary immune response to the $\mathrm{D}$ antigen occurs over 6 weeks to 12 months. It is usually weak, consisting predominantly of immunoglobulin $\mathrm{M}(\mathrm{IgM})$ that does not cross the placenta. As a result, the first pregnancy is not typically at great risk. Intrauterine transfusions have success rate of $80-90 \% .^{11}$

There remain lacunae and need for knowing biochemical abnormalities in relation to hypoalbuminemia, cardiac failure that can be attributed to late or non-resolution of hydrops. Finding the biochemical markers will help in predicting the development of hydrops/prognosis of hydrops/resolution of hydrops, or even fetal therapy.

The present study attempted to investigate whether any other alteration in fetal biochemistry is present in fetuses with various degrees of anemia with or without hydrops, which can determine the severity of fetal disease also whether the changes in biochemical parameters can have prognostic value.

In a study by Nicolaides et al to find the relationship of fetal plasma protein concentration in development of hydrops in rhesus isoimmunization. Fetoscopic samples of pure fetal blood were obtained at 18 to 25 weeks' gestation the plasma total protein was less than 2 standard deviations below the mean of the normal range in all hydropic fetuses and in six of 10 of those without hydrops. ${ }^{12}$ Hypoalbuminemia was found in six of the seven hydropic fetuses and in two of the non-hydropic fetuses. Marianowski L et al, found that in those hydropic cases where, the administration of only packed red blood cells produces unsuccessful results, albumin supplementation paralleled with PRBC injection significantly increases the effectiveness of intravascular treatment. $^{13}$

\section{CONCLUSION}

This study is one of the few studies which compared the biochemical parameters in fetal blood between normal, non-hydropic and hydropic fetuses in pregnant women with $\mathrm{Rh}$ isoimmunisation. This study also investigated whether any other alteration in fetal biochemistry is present in fetuses with various degrees of anemia with or without hydrops, which can determine the severity of fetal disease.

There was hypoalbuminemia in hydropic and nonhydropic group as compared to control group and more severe in severe hydropic as compared to mild hydropic group.

Funding: No funding sources

Conflict of interest: None declared

Ethical approval: The study was approved by the Institutional Ethics Committee

\section{REFERENCES}

1. Sullivan JF, Peckham NH, Jennings ER. Rh isoimmunization: its incidence, timing, and relationship to fetal-maternal hemorrhage. Am J Obstet Gynecol. 1967;15:877-80.

2. Liley AW. Liquor amnii analysis in management of pregnancy complicated by rhesus sensitization. Am $\mathbf{J}$ Obstet Gynecol. 1961;82:135-9.

3. Liley AW. Errors in the assessment of hemolytic disease from amniotic fluid. Am J Obstet Gynecol. 1963;86:485-94.

4. Trainor B, Tubman. The emerging pattern of hydrops fetalis-incidence, aetiology and management. Ulster Med J. 2006;75:185-6.

5. Snyder EL. Prevention of hemolytic disease of the newborn due to anti-D. Prenatal/perinatal testing and $\mathrm{Rh}$ immune globulin administration. Am Assoc Blood Banks. 1998;1:321-35.

6. Nicolini U, Nicolaidis P, Tannirandorn Y, Fisk NM, Nasrat H, Rodeck CH. Fetal liver dysfunction in Rhalloimmunization. $\mathrm{Br} \mathrm{J}$ Obstet Gynaecol. 1991;98:287-93.

7. Radunovic N, Lockwood CJ, Alvarez M, Plecas D, Chitkara U, Berkowitz RL. The severely anemic and hydropic isoimmune fetus: changes in fetal hematocrit associated with intrauterine death; Obstet Gynecol. 1992;79:390-3.

8. Mari G, Deter RL, Carpenter RL. Noninvasive diagnosis by Doppler ultrasonography of fetal anemia due to maternal red cell alloimmunization. Collaborative group for Doppler assessment of the blood velocity in anemic fetuses. $\mathrm{N}$ Engl J Med. 2000;342:9-14.

9. Sohan K, Carroll SG, Fuente SD, Soothill P, Kyle P. Analysis of outcome in hydrops fetalis in relation to gestational age at diagnosis, cause, and treatment. Acta Obstet Gynecol Scand. 2001;80:726.

10. Nicolaides KH, Soothill PW, Clewell WH, Rodeck $\mathrm{CH}$, Mibashan RS, Fetal haemoglobin measurement in the assessment of red cell isoimmunisation. Campbell S. Lancet.1988;14:1073-5.

11. Deka D, Buckshee K, Kinra G. Intravenous immunoglobulin as primary therapy or adjuvant therapy to intrauterine fetal blood transfusion: a new approach in the management of severe $\mathrm{Rh}$ - 
immunization. J Obstet Gynaecol Res. 1996;22:5617.

12. Nicolini U, Nicolaidis P, Tannirandorn Y, Fisk NM, Nasrat H, Rodeck CH/ Fetal liver dysfunction in $\mathrm{Rh}$ alloimmunization. $\mathrm{Br} \quad \mathrm{J}$ Obstet Gynaecol. 1991;98:287-93.

13. Marianowski L, Debski R, Rokicki T, Pasek K, Lukaszewicz E, Gromadzki J, et al. Albumin and packed red blood cells in the treatment of severely isoimmunised pregnancies. Materia medica Polona. Mater Med Pol. 1992;24:260-1.

Cite this article as: Yadav V, Deka D, Sharma A, Dadhwal V. Comparing difference in mean total protein, albumin and globulin based on severity of rhesus isoimmunization: a prospective study. Int J Reprod Contracept Obstet Gynecol 2020;9:3042-6. 